\title{
Microgreens: The treasure of Nutrients
}

\author{
Nidasesi Deepa* and Daneshwari Malladadavar \\ Department of Food Technology, University of Agricultural Sciences, \\ Dharwad - 580005, Karnataka, India \\ *Corresponding author
}

\section{A B S T R A C T}

Keywords

Green Leafy

Vegetables;

Microgreens; Shelf

life.

\section{Article Info}

Accepted:

05 January 2020

Available Online:

10 February 2020
Microgreens are emerging speciality food products which are gaining popularity and increased attention nowadays. Microgreens are tiny and tender counterpart of mature green leafy vegetables, contained higher amounts of minerals and vitamins (Platel and Srinivasan, 2017). Depending upon the variety of seed sown, microgreens are harvested between period of 7 to 21 days after sowing. Microgreens are tiny in size but they have dense source of nutrients. They are considered as functional foods which contain health promoting or disease preventing properties that are additional to their normal nutritional values. These greens can be a good way to fight against food security with their short growing season.

\section{Introduction}

In the world there are currently about 1 billion people chronically malnourished and approximately 2 billion people who suffer from a deficiency of essential micronutrients (Godfray et al., 2010; Godfray and Garnett, 2014). To address the need of a diet with fresh, nutrient-rich and high content of phytocompounds necessary for healthy development of the body, the vegetables industry has introduced a new product: microgreens. The microgreens can be considered an innovation of the concept of vegetables and vegetables industry in general, having the potential to transform the whole idea of vegetables (Di Gioia and Santamaria, 2015).

The microgreens are normal plants sown at a medium to high density and harvested shortly after the first true leaves emerge. Harvesting is done by cutting the stem just above the soil in which they grow or above the roots if the cultivation method is without soil. The time period from sowing to harvest is generally between 7 and 14 days, exceptionally reaching up to 21 days for some species with slower 
development, like celery. Microgreens include many common vegetables and herbs. Different types of microgreens include: cabbage, radish, turnip, carrot, beet, chard, pea, broccoli, kale, bok choy, celery, sesame, amaranth, cress, lettuce, endive, arugula, mustard, sunflower, alfalfa, clover, sorrel, canola, chia, flax, fennel, dill, basil, cilantro, and chervil. Microgreens are planted with the same seeds that are used to grow their fullsized counterparts.

Microgreens are tiny in size but they have dense source of nutrients. This may be due to the germination process from dry seeds to growing plants which involves many metabolic activities and de novo synthesis of nutrients. As the seeds germinate and the seedling emerge and develop, the content of protein and the balance of essential amino acids may be increased.

Microgreens have many beneficial facts over mature greens viz., microgreens contain higher concentrations of functional components such as vitamins, minerals and antioxidants than found in mature greens or seeds (Janovska et al., 2010).

Over sprouts which are usually produced in the dark with a very short production cycle, microgreens benefit of the surrounding environment, taking full use of light conditions and nutrients from the soil or alternative growing substrates.

Over the baby leaf vegetables, which need to be harvested through a cut and then commercialized losing nutrients before reaching the final consumer, microgreens can be sold keeping the plantlets alive in the soil or the growing media and the final consumer can cut the product minutes before usage. This innovation of selling the product while it is still growing guarantees a longer shelf life and assures a high quality in terms of both freshness and nutritional value (Di Gioia and Santamaria, 2015).

\section{Growing of microgreens}

Microgreens are easy to grow and easy to cultivate in small space. Microgreens may be grown: in farm or indoor under natural/artificial light sources, they can be grown in soil or soilless media. Microgreens can be grown by individuals at a small scale in kitchen or at a large scale, in industrial production systems, for commercial marketing. Growing, harvesting and postharvest handling may have a considerable effect on the accumulation and degradation of phytonutrients in microgreens.

\section{Substrate aspects}

The traditional soil cultivation for microgreens is recommended for individual growers but at large scale, hydroponic growing systems work better. In these systems different soilless growing media are used. The main soil substitute substrates used for microgreens production are peat-based mixes and synthetic mats. Since these types of substrates are expensive and non-renewable, scientists tried to find alternative solutions.

Di Gioia et al., (2016) showed that beside polyethylene terephthalate and peat, other alternative cheap substrates can be used (textile fibre and jute-kenaf-fibre). The choice of the growing medium represents one of the most critical aspects with a considerable impact on the productivity, quality and safety of microgreens.

\section{Production of microgreens}

Microgreens are grown in a standard, sterile, loose, soil, and many mixes have been used 
successfully with peat, vermiculite, perlite, and bark (Kou et al., 2013). Partially fill a tray with the media of choice to a depth of $1 / 2$ inch to 1 or 2 inch. Most crops require little or no fertilizer, as the seed provides adequate nutrition for the young crop (Xiao et al., 2015).

An alternative production system uses one of several materials as a mat or lining to be placed in the bottom of a tray or longer trough. These materials are generally fiberlike and provide an excellent seeding bed.

Some longer-growing microgreen crops, such as micro carrot, dill, and celery, may benefit from a light fertilization applied to the tray bottom. Some of the faster-growing greens, such as mustard cress and chard, may also benefit from a light fertilization because they germinate quickly and exhaust their selfcontained nutrient supply quickly.

Light fertilization is best achieved by floating each tray of microgreens for 30 seconds in a prepared nutrient solution of approximately 80 ppm nitrogen.

\section{Harvesting of microgreens}

Danielle et al., (1999) reported that microgreens are harvested at first true leaf stage, usually at about 2 inch tall and the time from seeding to harvest can vary greatly by crop from 7 to 21 days. Microgreens are usually harvested when the plants are 1 to 3 inches tall (Xiao et al., 2012).

Harvested microgreens are highly perishable and should be washed and cooled as quickly as possible. Microgreens are usually packed in small, plastic clamshell packages and cooled to recommended temperatures for the crops in the mix. (Danielle et al., 2011).

\section{Disadvantages associated with microgreens} production

\section{Short shelf life with the reduction in nutritional value during storage}

Industrial production and marketing of microgreens is limited by their short shelf life associated with rapid deterioration in product quality. There are various pre and postharvest techniques applied currently to extend the shelf life of microgreens. Shelf life of Microgreens:

Harvested microgreens are highly perishable, the shelf life of microgreens depends on many factors such as temperature, relative humidity, packaging film type and microbial load. Various techniques are used to enhance the shelf life of microgreens. The two important techniques used extend the shelf life of microgreens are storage temperature and storage atmospheric conditions (Hodges and Toivonen, 2008).

Modified atmospheric packaging technology effectively increasing the shelf life by decreasing oxygen, increasing carbon dioxide and partial pressures in the package headspace due to the interaction between respiratory oxygen uptake and carbon dioxide evolution of the packaged plant tissues and the selective transfer of gases through packaging films (Kim et al., 2004).

The selection of suitable packaging film is essential to maintain quality and to assure a longer shelf life of the produce (MartinezRomero et al., 2003; Chandra et al., 2012). The low storage temperature of fresh vegetables reduces both physiological activities like respiration rate and the biological activities of microorganisms capable of causing spoilage of the produce (Oliveira et al., 2015). 
Kou et al., (2013) studied the effect of storage temperature and modified atmosphere packaging on quality and shelf life of buckwheat microgreens. Results indicated that Buckwheat microgreens stored at 5 and $10{ }^{\circ} \mathrm{C}$ with moderately high oxygen (14.0 to $16.5 \mathrm{kPa}$ ) and moderately low carbon dioxide $(1.0$ to $1.5 \mathrm{kPa})$ level is optimal for the highest quality attributes and for a maximal shelf life. Shelf life of microgreens can also be extended using some pre-harvest techniques. Kou et al., (2014) investigated the effect of pre-harvest calcium application on the quality of broccoli microgreens. The postharvest quality and the shelf life of the treated microgreens increased to 21 days. The nontreated microgreens were edible only 14 days.

\section{Nutritional quality of microgreens}

An important strategy to increase the intake of health related bioactive substances is to increase the concentration in food plants. Thus, microgreens belong to the group known as functional food. Different microgreens contain widely differing amounts of functional compounds like antioxidants, minerals, vitamins and phenolics (Blomhoff, 2010). Growing, harvesting, and storage conditions may have a considerable effect on nutrient content.

Xiao et al., (2012) assessed the concentration of vitamins and carotenoids in 25 microgreens. The highest concentration of vitamin $\mathrm{C}$, carotenoids, phylloquinone and tocopherols were found in red cabbage, cilantro, garnet amaranth and green daikon radish.Microgreen cotyledon leaves possess higher nutritional value than the mature leaves. Microgreens contains about five times greater levels of vitamins than in their mature plant counterparts (Xiao et al., 2012).

The study conducted by Xiao et al., (2016) demonstrated that Brassicaceae microgreens are good sources of macroelements (potassium and calcium) and microelements (iron and zinc).

Sun et al., (2013) conducted a comparative study in five Brassica species. The results showed that microgreens contain more variety of complex polyphenols than mature plants, thus proving that microgreens are an important source of bioactive substances. Lettuce contains various health-promoting phytochemicals, including vitamins and phenolic compounds with antioxidant properties. The chemical analysis conducted by Xiao et al., (2015) revealed that China rose radish, opal basil and red amaranth have the highest concentrations of total ascorbic acid, phylloquinone, carotenoids and tocopherols while the highest concentrations of total phenolics were found in China rose radish, and opal basil.

Pinto et al., (2014) compared mineral profile of microgreens and mature lettuces. Result indicated that microgreens possess a higher content of most minerals such as $\mathrm{Ca}$ and $\mathrm{Fe}$ than mature lettuces. They concluded that microgreens can be considered as a good source of minerals in the human diet. Ahmad et al., (2016) reviewed the studies on bioactive components of microgreens and conclude that microgreens provide high concentration of vitamins and minerals which are linked with the promotion of good human health.

Carolyn (2016) assessed the nutrient contents of lettuce and cabbage microgreens grown hydroponically and on vermicompost and then compared to each other as well as to the nutrient contents of mature vegetables. Result showed that particularly high nutrient ratios were observed for iron in cabbage microgreens grown on vermicompost. 
Iron was 54.6 times higher than mature vegetable, while in case of hydroponically grown microgreens iron was 5.4 times higher than the mature vegetable. This review paper revealed that, the production of microgreens is a great advance in horticulture. Micro greens are tiny in size but they are dense source of ascorbic acid, tocopherols, carotenoids, phylloquinone, phenols, micro and macro minerals.

There are not sufficient scientific data to prove the higher level of nutrients in microgreens than in mature plants. In the above discussed studies, it was clearly proved that microgreens are better source of nutrients than their mature counterparts viz, vitamins and minerals content.

There's still a lot of debate regarding the health benefits of consumption of microgreens. Growing microgreens can be very productive and this advantage can be used to solve the growing demand of food. The storage shelf life of microgreens is an important concern as they are harvested in tender leaves stage. In above discussion few studies showed that microgreens shelf life and nutritive quality is depends on type of packaging materials and stored condition.

Therefore, further investigation and research is necessary for optimizing storage conditions and suitable packaging material for microgreens. However, it is important to create awareness in common people about its health claims, nutritional facts and its importance in daily life along with growing microgreen industry.

\section{References}

Ahmad, M. S., Shah, M. A., Maqbool, M. M., 2016, Microgreens: production, shelf life and bioactive components. Food
Sci. Nutr., 21: 14-19.

Bliss, R. M., 2014, Specialty Greens Pack a Nutritional Punch. Agric. Res., 62(1), 10.

Blomhoff, R., 2010, Role of dietary phytochemicals in oxidative stress. In bioactive compounds in plants benefits and risks for man and animals. Bernhoft, A, Ed. Proceedings from a symposium held at the Norwegian Academy of Science and Letters. Oslo: AIT Otta AS. 52 - 70.

Carolyn, F. W., 2016, Nutrient content of Cabbage and Lettuce microgreens grown on vermicompost and hydroponic growing pads. J. Hortic., 3(4): 100-190.

Chandra, D., Kim, J. G. and Kim, Y. P., 2012. Changes in microbial population and quality of microgreens treated with different sanitizers and packaging films. Hort. Env. Biotech. 53, 32-40.

Danielle, D. T., Hochmuth, R., Landrum, L. and Laughlin, W., 1999, Microgreens: A new specialtycrop. J. Hortic., 3: 16-20.

Danielle, D., Treadwell, Hochmuth, R., Landrum, L. and Wanda Laughlin, 2011, Microgreens: a new specialty crop. University of Florida IFAS Extension, 6-13.

Di Gioia, F. and Santamaria, P., 2015, Microgreens - novel fresh and functional food to explore all the value of biodiversity. Bari: ECO-logica srl.

Di Gioia, F., De Bellis, P., Mininni, C., Santamaria, P. and Serio, F., 2016, Physicochemical, agronomical and microbiological evaluation of alternative growing media for the production of rapini (Brassica rapa L.) microgreens. J. of the Sci. of Food and Agric., 15(5), 69-90.

Godfray, H. C. J., Beddington, J. R., Crute, I. R., Haddad, L., Lawrence, D., Muir, J. F., Prety, J.,Robinson, S., Thomas, S.M. and Toulmin, C., 2010, Food security: 
the challenge of feeding 9 billion people. Science (New York, N.Y.), 327 (5967), 812-8.

Godfray, H. and Garnett, T., 2014, Food security and sustainable intensification. Philosophical transactions of the Royal Society of London. Series B, Biological sci., 369: 20120273.

Hodges, D. M. and Toivonen, P. M. A. (2008). Quality of fresh-cut fruits and vegetables as affected by exposure to abiotic stress. Postharvest Bio. Tech., 48, 155-162.

Janovska, D., Stockova, L. and Stehno Z., 2010, Evaluation of buckwheat sprouts as microgreens. Acta Agri. Slov., 95: 157162.

Kim, J., Luo, Y. and Gross, K. (2004). Effect of package film on the quality of freshcut salad savoy. Postharvest Bio. Tech. 32, 99-107.

Kou, L., Luo, Y., Yang, T., Xiao, Z., Turner, E. R., Lester, G. E., Wang, Q. and Camp, M.J., 2013, Postharvest biology, quality and shelf life of buckwheat microgreens. Food Sci. Tech., 51, 7378

Kou, L., Yang, T., Liu, X. and Luo, Y., 2014, Effects of pre- and postharvest calcium treatments on shelf life and postharvest quality of Broccoli microgreens. Hort. Sci., 50(12):1801-1808.

Martinez-Romero, D., F. Guillen, S. Castillo, D. Valero, and M. Serrano. (2003). Modified atmosphere packaging maintains quality of table grapes. J. Food Sci. 68, 1838-1843.

McClung, C. R., 2014, Plant science. Making hunger yield. Science (New York, N.Y.),
344(6185), 699- 700.

Oliveira, M., Abadias, M., Usall, J., Torres, R., Teixido, N. and Vinas, I. (2015). Application of modified atmosphere packaging as a safety approach to freshcut fruits and vegetables-A review. Trends Food Sci. Tech., 46, 13-26.

Pinto, E., Agostinho, A., Almeida., Ana, A. Aguiar and Isabel, M. P. L. V. O. F., 2014, Comparison between the mineral profile and nitrate content of microgreens and mature lettuces. $J$. Food Comp. Anal., 37: 38-43.

Platel, K. and Srinivasan, K., 2017, Nutritional profile of Chekurmanis (Sauropus androgynus), a less explored green leafy vegetable. Indian J. Nutr. Diet., 54: 243252.

Sun, J., Xiao, Z., Lin, L., Lester, G. E., Wang, Q., Harnly, J. M., \& Chen, P., 2013, Profiling polyphenols in five brassica species microgreens by UHPLC-PDAESI/HRMS. J. of Agric.and Food Chem., 61(46), 10960-10970.

Xiao, Z., Lester, G. E., Luo, Y., \& Wang, Q., 2012, Assessment of vitamin and carotenoid concentrations of emerging food products: Edible microgreens. $J$. of Agric. and Food Chem., 60(31), 76447651.

Xiao, Z., Bauchan, G., Nichols-Russell, L., Luo, Y., Wang, Q., \& Nou, X., 2015. Proliferation of Escherichia coli O157:H7 in Soil-Substitute and Hydroponic Microgreen Production Systems. J. of Food Protection, 78(10), 1785-1790.

\section{How to cite this article:}

Nidasesi Deepa and Daneshwari Malladadavar. 2020. Microgreens: The treasure of Nutrients. Int.J.Curr.Microbiol.App.Sci. 9(02): 18-23. doi: https://doi.org/10.20546/ijcmas.2020.902.004 